

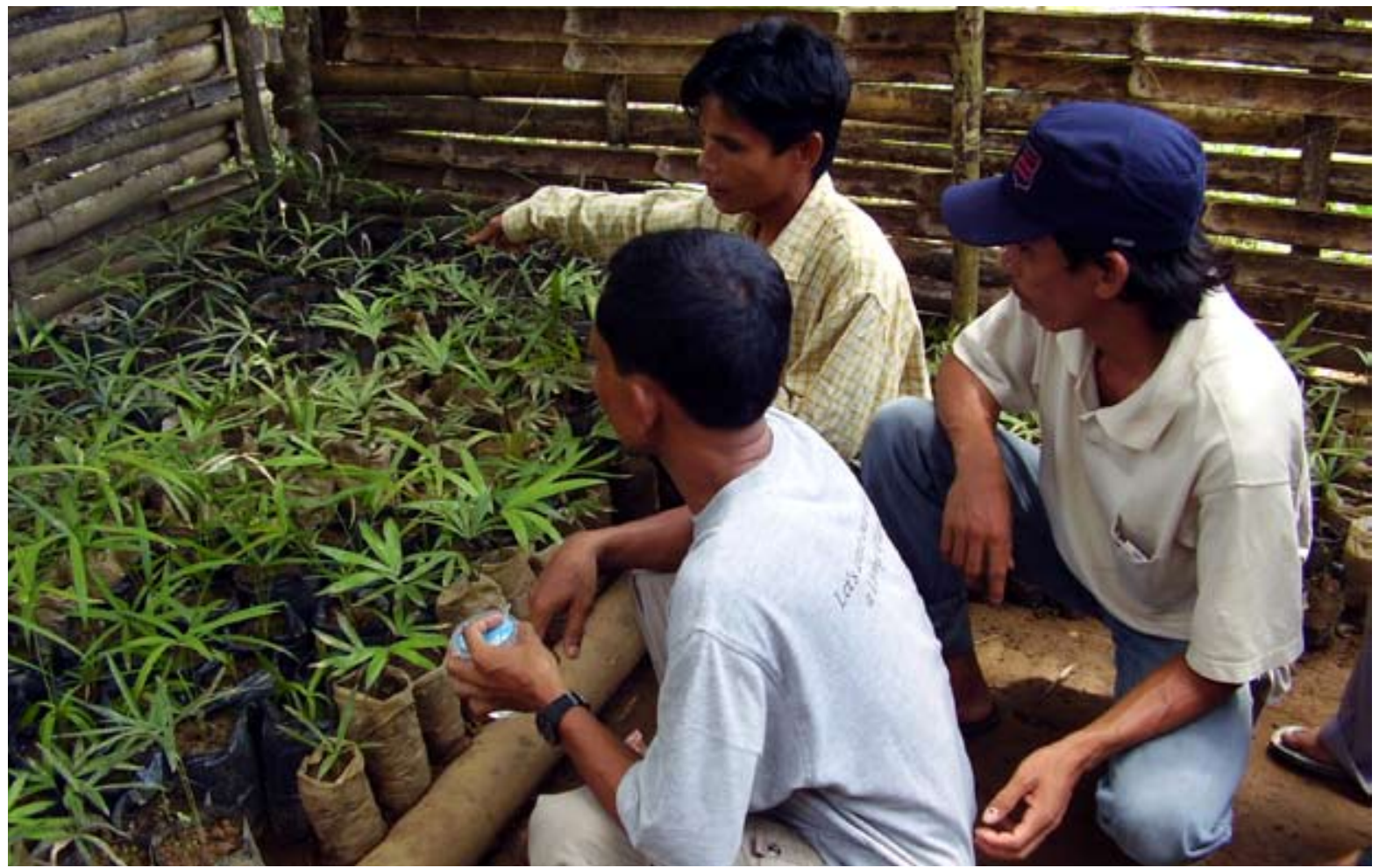

Reaping benefits from limited resources

The Center for International Forestry Research (CIFOR) is a member of the Consultative Group on International Agricultural Research (CGIAR). CIFOR, with local governments in the districts of Bungo and West Tanjung Jabung in Jambi Province, carried out the participatory action research reported here as part of the CGIAR's System-wide Initiative on Collective Action and Property Rights (CAPRi).

\section{Collective action and property rights}

Collective action can be defined as action taken by a group of individuals, either directly or on their behalf through an organization, in pursuit of the group members' perceived shared interests (Marshal 1998). The group may be formed voluntarily or be formally or informally instigated by external institutions. Collective action occurs when more than one individual is required to contribute to achieve an objective (Ostrom 2004). In this study, collective action can also be defined as conscious action taken together by local stakeholders to take advantage of social and political processes and opportunities provided by development plans. Sometimes, collective action can provide opportunities for an individual to overcome his or her limitations in terms of resources, power, capacity and voting rights.
Generally, policy makers and society define property rights as the privileges of either state or private ownership. Although individual opinions on the basic concept of property rights differ, a broad common understanding of property rights is important. Bromley, in Meinzen-Dick et al. (2001), defines property rights as the capacity to call upon the collective to stand behind one's claims to a benefit stream. In our case, our interest in rights is broader than only ownership, but also implies the right to secure or receive benefits through the legal agreement of a social group, either large or small.

In the context of communities living on the borders of forests, property rights are not seen only as the right to exercise exclusive control over a resource, but also the right to utilize that resource. In Indonesia, forest management and use rights are regulated by the state; they include, e.g., state rights over forest land and rights over "areas for other land uses" (APL) used for non-forestry purposes. Land classified as state forest belongs to the state, and the authority to manage it is held by the Ministry of Forestry. For regions outside forest areas the authority to manage land can be held by the state, the private sector or communities. At the community level, the state recognizes both individual and communal traditional rights (adat). 


\section{Forests - land security and what it means to communities}

Land is a non-expandable resource. For years communities have lived with the social rules that shape them, with land ownership being an integral part of this culture. In addition to its social role, land also has an economic role in that poor farming communities depend on it for their livelihoods. In Indonesia, cultural and social norms govern the management of resources and how they are distributed. It is a long-standing cultural tradition to pass land down to one's children. However, what happens when this non-expandable resource has to support an ever-growing population and other external factors?

Population growth, due either to an increase in the birth rate or to immigration into a region, is spurring the increasing demand for land as a source of livelihoods. When one's land is no longer sufficient to be subdivided and to meet basic needs, a farmer will look for other land to meet the shortfall. Consequently new land is cleared to expand the area available for agriculture, not only in the vicinity of the village but also in the surrounding forest thereby leading to land conflict. Basically, communities see land security as their having management rights over natural resources.

The need for land security, either through legal ownership status or management rights, was an important issue in the two villages that were the subject of this study, where purchased or inherited land is not accompanied by any certification or proof of ownership. Villagers' concerns increased when they were asked critical questions about ownership, particularly about the legal status of their land and the risks they face if it has no such status. The villagers voiced these concerns on their own initiative.

The decentralization of forestry management has opened up the opportunity to assess how decentralized policies can influence community livelihoods and forests. There are fundamental issues to be taken into consideration that in time will directly or indirectly affect communities and forests.

\section{Research Approaches}

This paper explains the process and findings based on a study adopting Participatory Action Research (PAR) undertaken in the villages of Sungai Telang in
Bungo District and Lubuk Kambing in West Tanjung Jabung District, Jambi Province. PAR is a research approach used to build shared learning processes among the members of a group. PAR seeks to bring together action and reflection, theory and practice, in participation with others, in the pursuit of practical solutions to issues of pressing concern to people, and more generally the flourishing of individual persons and their communities (Reason and Bradbury quoted in Brydon-Miller et al., 2003). The PAR process aimed to strengthen community groups who were working collectively.

The process took the form of direct facilitation to support the community to become involved in wider networks of stakeholders in government development programmes. In order to focus on group-strengthening processes, a facilitator was deployed in each village to study group dynamics. Groups were chosen based on how they had been formed, gender and ethnicity of the members, how long the group had been in existence and what its objectives were. Those selected were existing men's and women's groups that had formed in hamlets in each village.

The focus of the study was to facilitate two men's groups and two women's groups in each village. This brief describes the experiences of two of the community groups in their efforts to secure their rights over the land that provides their livelihoods. The two groups are Tunas Harapan in Lubuk Kambing, Tanjung Jabung Barat District, and Sinar Tani in Sungai Telang, Bungo District.

Tunas Harapan is an all-male group of migrant farmers of varied ethnic backgrounds; it comprises 34 members. The members of this group cultivate land together in the newest hamlet in Lubuk Kambing. Sinar Tani is an all-male village level organization consisting of farmers who aim to help smaller farmers within the group. The group members comprise various elements of the community such as village government officials, members of the village consultative assembly (BPD), community elders and other villagers.

Apart from the fact that they formed independently, these groups were chosen because of their strong and solid group characteristics; their members were highly motivated and committed to their groups. Their working rules still applied and reflected group integrity. Descriptions of both groups are presented in Table 1. In addition to their having the qualities described below, the groups were selected taking into account district-level decision-making processes in which the district government looks 
Table 1. Group characteristics

\begin{tabular}{|c|c|}
\hline Sungai Telang & Lubuk Kambing \\
\hline Sinar Tani & Tunas Harapan \\
\hline $\begin{array}{l}\text { - The group comprises } 17 \text { men from village and community } \\
\text { organizations and aims to help the smaller farmers in the } \\
\text { group to till their land. } \\
\text { - The group receives support from agricultural extension } \\
\text { officers (PPL). } \\
\text { - The group was formed when the government offered a } \\
\text { programme to improve rice field irrigation. } \\
\text { - The group's activities have been limited since it received } \\
\text { government aid in 1998, but members still engage in joint } \\
\text { activities. In } 2001 \text {, the group secured rice tillers from the } \\
\text { government, but only a few of the members were } \\
\text { interested in the project. }\end{array}$ & $\begin{array}{l}\text { - This all-male group consists of } 34 \text { men } \\
\text { of mixed ethnicity, all from one hamlet } \\
\text { of Suka Maju. } \\
\text { - Membership comprises immigrants } \\
\text { who need land for farming. } \\
\text { - The group's aim is to help each other to } \\
\text { work their agricultural land. } \\
\text { - The group was initially formed when } \\
\text { government introduced a program } \\
\text { providing aid to farmer groups for } \\
\text { developing oil palm in } 2000 \text {. }\end{array}$ \\
\hline
\end{tabular}

for certain group characteristics before providing aid.

This brief tries to answer the following questions:

- How can collective action play a part in securing various forms of property rights? What rules strengthen this collective action?

- How far can security of property rights support poor communities and maintain forest sustainability?

\section{Bridges of communications}

Encouraged by their new awareness of the importance of land status, villagers have tried both individually and collectively to obtain secure rights to their land. An example of this comes from Sungai Telang, when the community expressed a need for a high school for village children. This raised the issue of obtaining certified land on which to build the school. The many questions that arose encouraged the community to seek more information on the possibility of obtaining certification for private farm land. They indicated that they were interested in certifying their land because the area of land available in the village for the next generation is diminishing. 'Many young married couples do not have land, and must therefore open up new land, often far away and difficult to reach,' said one of the group members during an informal chat at a community meeting in the village.

After a series of visits made by the group members and the village facilitator to the district agencies to find out more about the procedures for land certification and the requirements to be fulfilled, it was agreed to hold a village meeting to clarify what

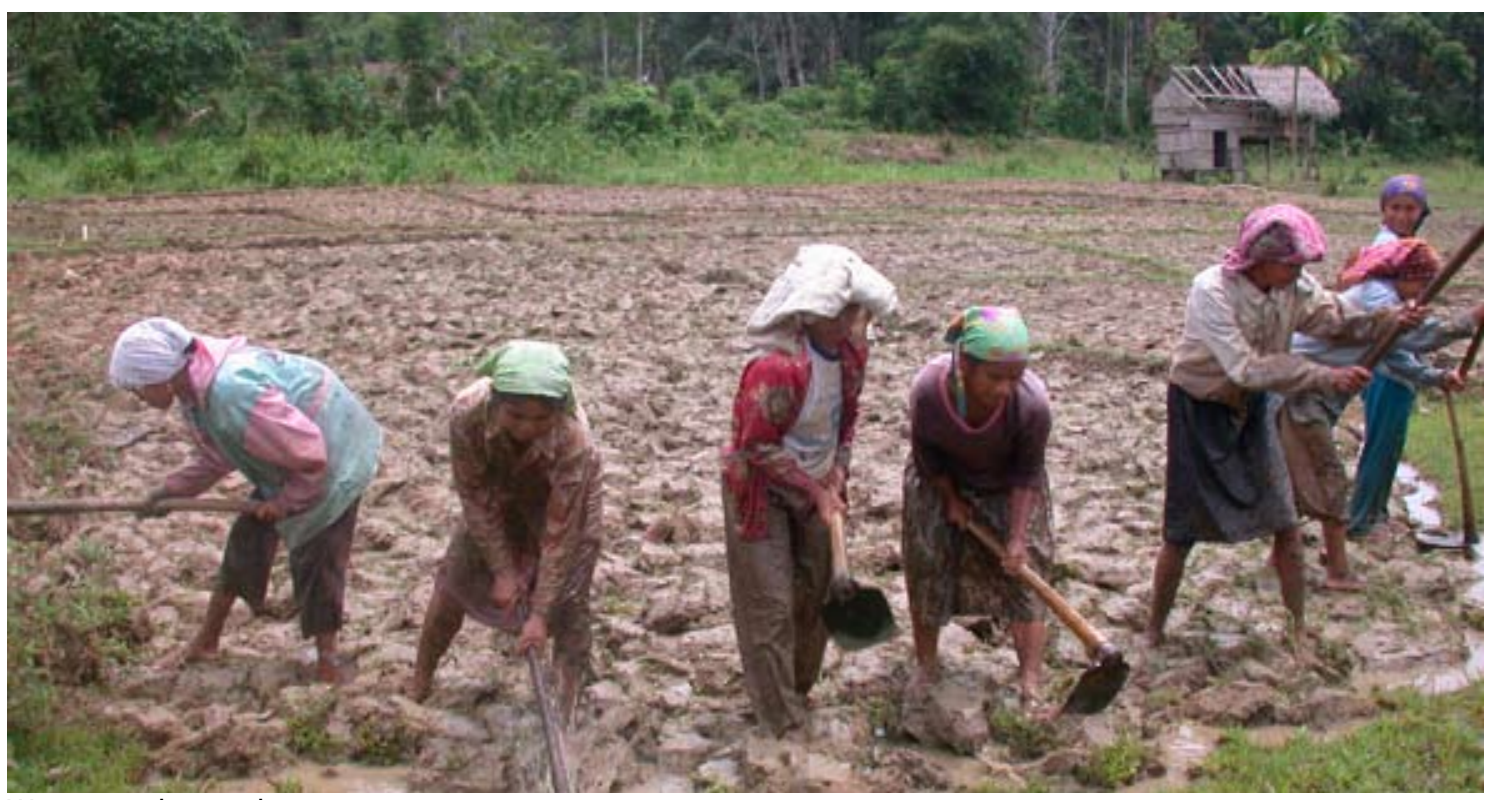

Women and natural resource management 
land certification really means. This meeting was attended by representatives from district agencies such as the National Land Agency (BPN), forestry agency (Dishutbun), the Regional Planning Agency (Bappeda) and the community of Sungai Telang, both men and women. The process also attracted other community members from neighbouring villages who were interested in learning more about land certification.

The meeting created sufficient space for discussions and the community raised many questions - ranging from very basic issues such as what certification means to more complicated ones such as the procedure for and cost of land certification - that were answered by various government officials and the agricultural extension agents. Villagers were also updated on recent policies and regulations related to land. Not only the group, but the whole community felt the benefit of this discussion and considered it to have been a good opportunity to clarify matters related to land ownership. The meeting was followed by the group's submitting a proposal for mass land certification through the Indonesian National Agrarian Programme (PRONA). PRONA is a government programme aimed to provide mass certification of lands for poor people at low cost. The process is ongoing. Individually, villagers have striven to secure legitimacy for and recognition of their land rights through letters of land status notification (Surat Keterangan Tanah - SKT) and, occasionally, letters of land recognition (Surat Pengakuan atas Fisik Lahan), the two forms of land rights recognition known to the villagers, both of which are issued by village heads.

Farmer and other village groups engaged in a variety of collective activities as well. Through government extension programmes, the groups have learned about various government development programmes, participation in which would make it easier for them to secure more legally binding recognition of their land rights, i.e., land certificates.

This information was then shared with all communities. In theory, each district government in all the regions of Indonesia receives PRONA funds for allocation of 250 plots of land during each fiscal year. In reality, however, as government funds are limited not all regions can be covered, and in any one year only a few locations receive such assistance. In 2006, Bungo allocated 50 certificates for 4 villages, including 3 villages in Tanah Tumbuh subdistrict and 1 village in Bathin II subdistrict. Determination of priority villages, subject to elite capture, takes account of among others community needs and willingness.

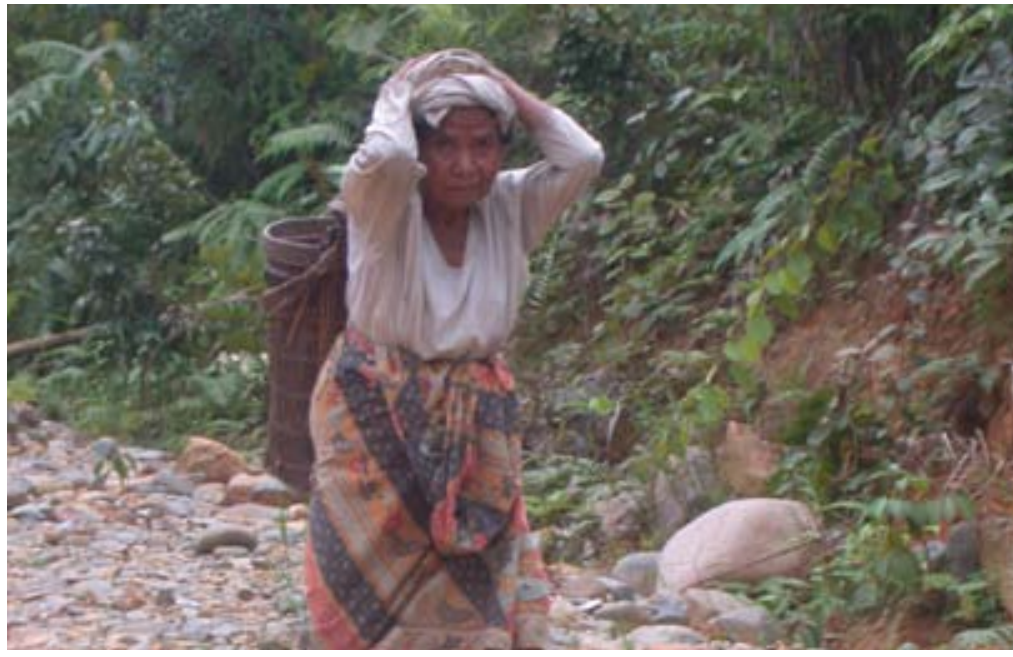

Woman in the middle of abundant resources

The Tunas Harapan group in Lubuk Kambing had similar experience. Because of these constraints, villagers tend not to rely on the PRONA programme to secure land rights, choosing instead to submit proposals collectively to procure support in the form of agricultural extension, tree crops seedlings, forestry, educational facilities and health materials. Some group members feel that the provision of some form of development aid is an early sign of acknowledgement of their existence and ownership in the region.

'The district head gave us a corrugated tin roof for the primary school building in our hamlet. That showed he already acknowledged the community in this hamlet.' (Villager from Suka Maju Hamlet)

'If the government has opened the road, it means our hamlet is recognized as a part of Tanjung Jabung Barat District.' (Villager from Suka Maju Hamlet)

Group members also feel that the various central and regional government development programmes rarely emphasize continued community access to natural resources, which is essential for the security of community property rights. Most aid is very short lived, with forestry and capacity-building support limited to the provision of saplings and advice on cultivation methods, with no evaluation of results or support to tend or secure benefits from the crops planted. Issues such as long-term incentives for communities to tend and harvest the produce of these crops - which of course relates to property rights - remain beyond the scope of these programmes. 
Another issue is that not all the information about these government programmes reaches the communities, and, equally, not all community aspirations are conveyed to the government. The facilitation processes carried out during this study formed a bridge for communications between villagers and others outside the village - the district government in particular.

To build communication, community group representatives were introduced to representatives from a number of government institutions. To broaden their insight and experience, community representatives were assisted to meet government staff from the subdistrict and district offices, who in turn were also helped to interact effectively with the villagers. Through discussions and meetings, both parties shared information and sought solutions to the problems that they jointly face. The Sinar Tani and Tunas Harapan groups acquired a great deal of information on forestry, plantations, agriculture and agrarian affairs. These processes were an integral part of the community groups' shared learning about preparing plans, acting on those plans, monitoring actions and reflecting on the processes. By repeating this series of steps, the villagers became more aware of their own potential and their existing resources. The process of introducing the local community to more of the stakeholders, particularly those who have direct power and are authorised to implement government policies, has slowly increased the self confidence of the individual stakeholders to negotiate when dealing with government officials. Their self confidence grew as they realized that the problems they were facing and steps they were taking were not theirs alone, but shared actions and needs.

\section{The early step}

In the two villages, the farmer group members worked together in their efforts to secure government recognition of their land rights. In Sungai Telang, the desire to secure ownership rights over private land emerged when villagers were faced with problems of land status if they inherited land without being able to prove their ownership. The tradition whereby inheritances are distributed verbally by community elders (ninik mamak) is still practised, site dimensions are often unclear, and boundaries are moved; these have all resulted in the farmers having no legal rights over their land. They wanted guaranteed access to the natural resources they have always managed.

The issue of lack of security of rights over natural resources became more pronounced when the
Sinar Tani farmer group gathered to assess the problem. They looked at and analyzed the issues facing them and tried to find ways to resolve the problems using the limited resources available to them. The group engages in collective farming activities in order to build trust among its members by helping them increase their personal capacity. By working as a group they hope to encourage the utilization of natural resources to secure optimum benefits from the produce of their traditional land management practices. The group is an association of individuals who all have land in one area. All the group members alluded to a recent problem that had occurred on their land when owners of neighbouring fields moved their boundary markers: it was difficult to prove what the original boundaries had been because the farmers had inherited their fields without ownership deeds. Minang, the local ethnic group hereditary customs are still employed in Sungai Telang when land to be inherited is divided. Ninik mamak elders share out the inheritances verbally; this is witnessed by community elders, but no proof of ownership or letters of inheritance are provided. Another problem is the use of unclear measurements when determining the size and borders of the inherited land. When land is bought or sold in the village, there is no proof of ownership or letter of transaction. Recognition of land ownership has always been based on trust only; now, however, group members realize the importance of proving ownership of their land.

To address this problem, the Sinar Tani group agreed that they shared a need to secure land certification as proof of recognition that they owned their land.Some members knew that such certificates were issued formally by the government, so the group agreed to work together and plan a collective proposal.

The group agreed that the first step was to meet regional government agencies to explain their problem. The group appointed a representative to meet with the District Bappeda, the first agency to be visited. The representative explained the group's aspiration to secure rights over land that they could now not prove they owned. Bappeda responded positively to the group's wish, and saw the community claim as coming at just the right time because the district government was explaining its programme to increase the people's awareness of the need for legal land security. An officer from the BPN and a representative from Bappeda visited the village and gave a talk on land certification.

The information they received on land certification processes encouraged the villagers to continue taking steps towards securing recognition of their land ownership. After discussions, the farmer group 
agreed to submit a collective proposal through the PRONA programme, choosing this approach because it was the easiest and cheapest way of securing legal land tenure and was supported by funding from the National Government Budget (APBN).

Once the farmer group had decided what to do, the next step was to prepare all the requirements for a PRONA programme application. The group members' enthusiasm and clear delegation of roles accelerated data collection. Collective action and the support of various parties in the village all helped the submission of the request to BPN.

Unfortunately, although BPN received the request, the group's application could not be immediately fulfilled: the head of Bungo District BPN told them that the district's PRONA quota of 250 certificates for 2005 had been used up by other villages that had submitted their requests in 2004.

The Sinar Tani members could do very little other than resign themselves to the situation. They hope to take the next opportunity, probably in 2007, to secure certification for their land.

\section{Expectation of secured livelihood sources}

For the Tunas Harapan group and the immigrants living in Suka Maju hamlet, in Lubuk Kambing, securing recognition of land tenure in the form of certification remains a dream. The land they have settled and now farm is in a production forest that has been controlled by several private, Commercial Forestry Concessions (Hak Pengusahaan Hutan $\mathrm{HPH}$ ) and Industrial Timber Estates (Hutan Tanaman Industri - HTI) companies over the years: PT. Sadar Nila (1977-1997), PT. Loka Rahayu (1977-1997), PT. Inhutani V (1997-2000), and now PT. Wira Karya Sakti (a 100-year lease beginning in 2004).

'Back in 1997, we all stood up to the PT. Inhutani V workers who wanted to flatten our land and our homes. All the women blocked the company's bulldozers. When PT. Inhutani $V$ questioned our identities we took off our blouses and bras and shouted, "Here are our identity cards".' (A woman from Suka Maju hamlet)

During interviews, some group members gave the impression they were not very concerned about ownership status. They do not have a close relationship with the land they have settled, so they were more inclined to hope that the government could provide access to and management rights over the utilization of natural resources. They also believed that if they benefited from a government programme it would be another form of government acknowledgement of their existence in the region. To date, most immigrant villagers have secured recognition of their rights over agricultural fields in the form of SKTs issued sporadically by the village head. Although they have no solid legal foundation, these sheets of paper containing information on land ownership and signed by the village head are considered to be a form of recognition, providing the villagers with a sense of security. They can at least use them to defend their land rights when issues arise involving claims by locals.

When members of the Tunas Harapan farmer group began considering their problems, one issue identified related to the underutilization of natural resources as the farmers' limited financial capacity meant that many areas remained unproductive. Unexpectedly, many of the villagers said that they wanted the government to pay attention to their farming activities and conveyed this message to the village head when he held a meeting with the villagers in Suka Maju hamlet. In one of the early meetings a villager said, 'There's a lot of land in this region, Sir, but there has never been any agricultural development. Please could you bring in agricultural extension agents (PPL) to guide us?'

In one meeting, members of the farmer group agreed to seek information on farming activities from the Merlung Subdistrict Agricultural Extension Office (BPP). With the help of facilitation, group representatives carried out regular visits to the BPP and opened up new hope for the group. BPP agents admitted that they felt 'reminded' that communities still needed their help. Communication between them commenced, and the group received a great deal of information about government agricultural programmes. The farmer group's wish for guidance received a positive response from BPP agents, who went to Suka Maju hamlet for a field meeting to gain a better understanding of community conditions and the potential of their agricultural land.

In group meetings the members learned to think about and prepare new plans, with each member putting forward a variety of ideas. Generally, the group wanted to secure government help with its farming but was faced with two choices: tree or food crops. Group members debated which to choose. Some members clearly based the choice on their personal interests and needs that they felt should be adopted by the whole group. However, 
after considering the needs of the majority and the resources available, the members finally agreed to submit a proposal to the government's programme on Estate Crops in Specific Areas (P2WK), hoping for indirect recognition of their tree crops.

When the decision had been made, the group members prepared a participatory action plan. They appointed a small subgroup and entrusted it with obtaining information with the help of the research team. From their discussions with the Merlung Subdistrict Forestry and Estate Crops Branch Office they obtained comprehensive information on the $\mathrm{P} 2 \mathrm{WK}$ programme, including on the procedures and preconditions for submitting aid proposals.

Once the plan was underway, a meeting was held to reflect on how things were proceeding, as for no apparent reason one member entrusted by the group was not doing his job. This is all part of the reality of farmer group dynamics. In actual fact, the reason was an internal conflict within the group. Some members considered the failing member's attitude to be 'treacherous'.

In a relatively short time the farmer group members had worked together and fulfilled all the requirements necessary to submit a P2WK proposal. Clear delegation of tasks within the group and enthusiasm for working together speeded up the preparation process. The members' expectations that they would secure the requested aid were a contributory factor.

Completion of the P2WK proposal, however, did not mean that the application process ran smoothly. Obstacles began to emerge when the farmer group asked for the village head's signature on the proposal they planned to submit. The village head was reluctant to sign the $\mathrm{P} 2 \mathrm{WK}$ proposal letter, claiming that the villagers submitting the proposal were not registered as inhabitants of Lubuk Kambing.

The group held a meeting to discuss the issue (see box below). The members were upset with the village head, judging his reason for rejecting the proposal to be tendentious and without foundation. However, although it dampened the farmer group's enthusiasm this obstacle did not stop them from submitting the proposal.

One idea that emerged during the meeting to discuss the village head's attitude to the proposal was to open communications with Merlung
Fierce debate broke out between members of the group when discussing the village head's reluctance to sign their P2WK request. There was considerable irony in the village head's claim that the farmers were not inhabitants of Lubuk Kambing as at the time of the election for village head the village government's interest in involving the people in Suka Maju in the election process had been clearly apparent. However, when the villagers needed support and recognition of their group, the village head's attitude obstructed the process.

A minority of members suggested cancelling the request because they worried that the village head would be angry if they continued with their plan and that this would have a negative effect on their presence in the region. Conversely, some members thought they should carry on by submitting their request through a different channel without having to obtain the village head's signature. Finally the group members agreed to continue with their request by trying to approach the village head again in the hope he might agree to sign the document. They agreed to assign a representative indigenous to Lubuk Kambing to talk with the village head, with the help of a facilitator.

The discussion with the village head went ahead, but without success. He remained unwilling to sign, saying that the P2WK proposal should have been submitted in the name of Lubuk Kambing and not on behalf of the Tunas Harapan group.

Subdistrict Government, a bold step that would bypass the village head. With the help of the subdistrict government, the request was finally forwarded to the relevant district authorities.

Unfortunately, however, the farmer group's hope of securing P2WK aid has still to be realized. The P2WK 50-ha programme quota for Merlung Subdistrict approved by the District House of Representatives (Dewan Perwakilan Rakyat Daerah - DPRD) for 2005 had already been allocated to farmer groups in other villages that had submitted proposals in 2004. Another problem that the farmer group had to face was that their P2WK might not be approved because the land proposed for it is located in a production forest and converting its status to an APL area (for other land uses) requires a long process at the central government level. 
On 2 February 2006 a meeting was held at the village head's house in Lubuk Kambing between Wira Karya Sakti (WKS), village authorities and community figures. During the meeting WKS explained its presence in the ex-Sadar Nila and Loka Rahayu production forest. At the time, WKS had already acquired the two companies' concession permits and was about to begin installing boundary markers between its concession area and the Koptas Kotalu oil palm estate.

During the meeting, the village authorities and community figures rejected WKS's claim and asked the company not to begin any work at all before the status of the land had been clarified. The village authorities and community figures insisted that they would not be responsible if villagers took action if WKS continued with its plan. WKS responded by discussing its plan further with Merlung Subdistrict Government.

In spite of the villagers' demands, the company continued with its plan to install boundary markers on its concession area. The villagers responded spontaneously by removing all the markers that had been installed. They also chased away company employees who wanted to start working in the region, mainly cutting paths and installing their own boundary markers. The villagers' resistance was not violent, but there was a chance that it might escalate into violence if a solution was not found quickly. As far as the villagers were concerned, they were only trying to defend the land they had cleared.

The villagers' efforts were not in vain and the regional government considered their aspirations. Hope emerged in a workshop on spatial planning and state forests in the provincial capital, when the district government, in its proposed revision to its spatial plan, included the area as part of a state forest that it intended to convert to an area for other land uses. The workshop was facilitated by the CAPRi research team on 27 April 2006 by bringing together various stakeholders to further explore problems and possible solutions. Although the Ministry of Forestry has yet to approve the revision, regional stakeholders have continued to take follow-up steps.

The company took the initiative of removing the disputed region from its concession area. Collaborating with the Jambi and West Tanjung Jabung forestry offices, the company made an inventory of the area the villagers had cleared. Some alternative solutions have also been discussed, including partnerships with the company, employing a community forestry system, and relocating the community to another region. Whether the community benefits from this process and whether the villagers will finally secure the property rights for which they long remains to be seen. This is an ongoing process and all stakeholders are learning from it.

The P2WK rubber crop programme proposal submitted by the Tunas Harapan farmer group in Lubuk Kambing was a community effort to secure indirect recognition of land rights.

\section{Reflections on property rights}

These two cases show that there are two ways in which 'property rights' can be understood: ownership rights and management rights, both of which - if clearly defined and upheld - can provide communities with security in managing their land. The first case, in Sungai Telang, illustrates the efforts of villagers who already own land to secure tenure through legal certification. The second case shows the efforts of villagers from a hamlet in Lubuk Kambing to seek land security in the form of management rights over land they are farming.

Property rights for villagers are not only ownership rights in the form of land certificates: they can also be defined as management rights over natural resources. These too can provide security and guarantees for their holders. Collectively, for instance, villagers managing land within state forests in the form of small-scale industrial timber estates (mini-HTI) or community forestry (Hutan Kemasyarakatan - $\mathrm{HKm}$ ), with clear rules on rights, responsibilities and timeframes, have an incentive to manage these resources in a more sustainable way.

This is a lesson for those with control over forest resources and a narrow view of property rights, who tend to be reluctant to talk about such issues. Villagers and other stakeholders such as regional governments should learn from the two cases described above that there are many options for managing resources and different ways of achieving community prosperity. Providing ownership rights and changing the status of state forest to 'areas for other land uses' are not the only options. The existence of transparent mechanisms, collaborative processes among stakeholders, clear rules and strict penalties for violations of those rules, makes it easier to manage natural resources in a more sustainable manner. 


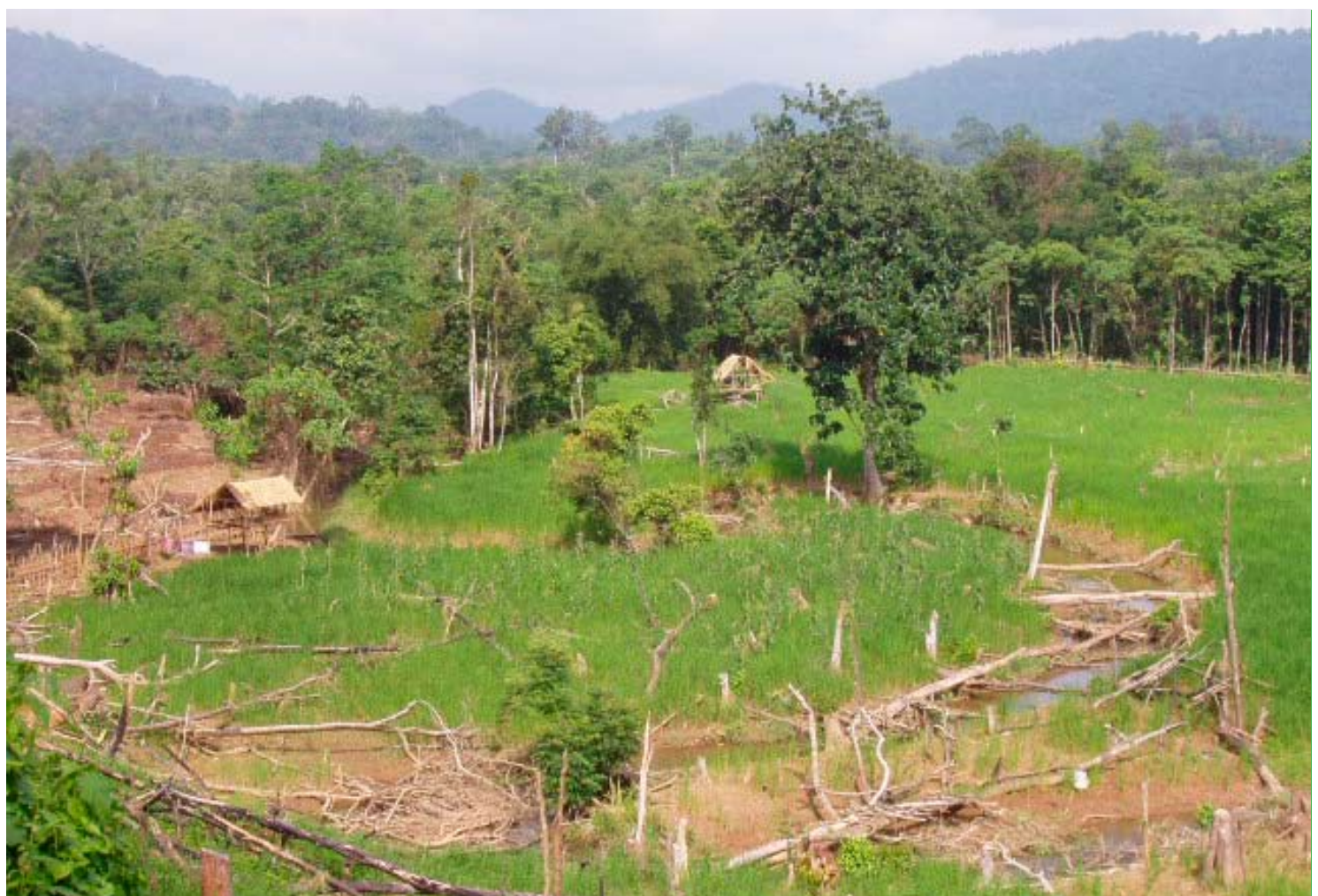

Jambi people's swidden system

\section{Lessons learned}

\section{Collective action is stronger than individual action}

Through the PAR processes used in this study individual group members learned how to act together to reach an objective. Shared interests are important and encourage groups to work together. The groups studied have rules agreed by consensus. These rules bind every individual in the group to remaining committed to achieving a shared objective. Although during a process there may be individuals who do not stand by their own commitments, the integrity and enthusiasm of the group as a whole to achieve its goal is not significantly affected. On one occasion, for instance, a group member tried to persuade the others not to attend a group meeting, saying that every time they met money was taken for group activities. Other members did not respond to him and left him to his own devices.

Through membership in a group, an individual's ideas may be shared with others, thereby offering more opportunities to find a solution to a problem. This was very apparent when the Tunas Harapan farmer group encountered a problem in the village head's refusal to sign its P2WK proposal. The members proposed and deliberated on many alternative solutions. They eventually found a way out of their dilemma and finally agreed on a solution that was unlikely to give rise to new issues.

Equal distribution of roles is important in a group; equality encourages strong feelings of responsibility in each individual toward the group's interests and leads to more informal relationships between its members. Each member feels that he or she has the same rights and obligations.

A group needs a leader who commands a high level of trust from its members. Good leaders are unifiers of individuals in a group, and the members' trust in their leader is a prerequisite for the success of a group. However, it is not easy to find a good leader. Personal conflicts between members can give rise to unhealthy competition that in the end erodes a leader's authority. Unfair competition for leadership often ends with one side being dissatisfied and provokes other members to bring down the leader.

\section{Collective action makes it easier to achieve shared objectives}

Ensuring that every group member has a role to play is the key to achieving shared objectives. With division of responsibilities, it is easier to complete jobs effectively and efficiently, in terms of both time and results. 


\section{Collective action reduces the chance of elite capture}

Elite capture often occurs because one party is stronger than the others. The equitable division of roles and responsibilities in a group is a strong deterrent to the emergence of elite capture in collective action.

\section{Government programmes are more open to groups of villagers}

Opportunities exist for community groups to secure aid through government policies and programmes. Various government programmes, e.g., P2WK, PRONA and Productive Economic Enterprises Aid, oblige community beneficiaries to form groups. In the forestry sector, policies on community forestry, forest product collection permits and miniHTI (some of these are no longer valid since the authority of district heads was revoked in 2002 and others are still in draft form) position community groups as programme beneficiaries.

\section{Group probity enhances government trust}

The government is more likely to trust a group than an individual to distribute funding and supervise and monitor a programme activity. Recent demands for programme implementation, such as government institutions being obliged to prepare accountability reports on government institutional performance (LAKIP) and performance-based budgets, reinforce the government tendency to place more trust in groups than individuals.

\section{Property rights can be defined more broadly}

An extremely important finding from the whole research process was that communities acknowledged that property rights did not have to always be defined narrowly as ownership rights (in the form of land certificates). They perceived that management rights alone could also provide the kind of security needed to ensure their livelihoods.

\section{References}

Bromley, D. (1991). Environment and Economy: Property Rights and Public Policy. Cambridge, MA: Basil Blackwell. Ch.s 1-4.

Brydon-Miller, M., Greenwood, D. and Maguire, P. 2003 Why Action Research? Action Research 1(1): 9-28.

Marshal, G. 1998 A Dictionary of Sociology. Oxford University Press, New York.

Meinzen-Dick, R., Knox, A. and Di Gregorio, M. (eds.) 2001 Collective Action, Property Rights and Devolution of Natural Resource Management: Exchange of Knowledge and Implications for Policy. DSE/ZEL, Feldafing, Germany.

Ostrom, E. 2004 Understanding Collective Action. In: Meinzen-Dick, R.S. and Di Gregorio, M. (eds.) Collective Action and Property Rights for Sustainable Development. Brief 2 of 16. International Food Policy Research Institute (IFPRI), Washington D.C. 
This brief is part of the findings of a research project entitled "Collective Action to Secure Property Rights for the Poor: Avoiding Elite Capture of Natural Resource Benefits and Governance Systems", which is a cooperative effort between CIFOR, CGIAR System-wide Program on Collective Action and Property Rights (CAPRi), International Food Policy Research Institute (IFPRI), and Bungo and Tanjung Jabung Barat District Governments, Jambi Province. The research has been funded by the German Federal Ministry for Economic Cooperation and Development (BMZ). ACIAR (Australian Center for International Agriculture Research) has also partially provided funding for translating and editing the brief. Disclaimer: The opinions expressed herein are those of the authors and do not necessarily reflect the views of CIFOR, partner institutions and the funding agency. This article will also appear in a CIFOR collection being developed by Adnan et al.
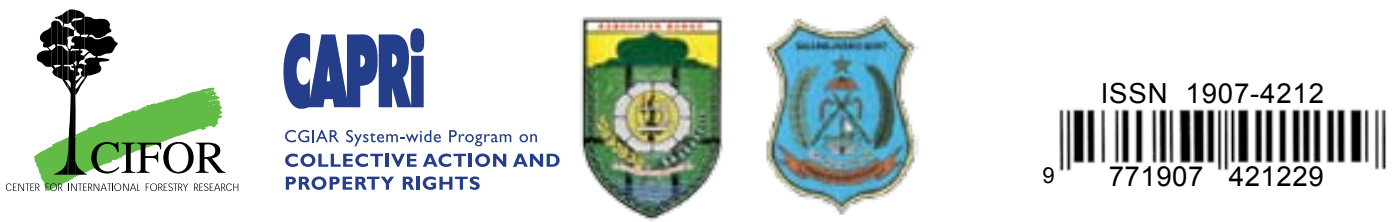

Center for International Forestry Research, CIFOR

Tel: +62(251) 622622 Fax: +62(251) 622100

Office address: Jalan CIFOR, Situ Gede, Sindang Barang Bogor

E-mail: cifor@cgiar.org

Barat 16680 , Indonesia

Mailing address: P.O. Box. 6596 JKPWB

Jakarta 10065, Indonesia

Website: www.cifor.cgiar.org

Photos by Yentirizal, Hasantoha Adnan and Yuliana Siagian

CIFOR's Forests and Governance Programme examines how decisions about forests and forest-dependent people are made and implemented in order to promote the participation and empowerment of disadvantaged groups; the accountability and transparency of decision-makers and more powerful groups; and democratic, inclusive processes that support fair representation and decision making among all groups. 